\title{
Kepuasan Mahasiswa Terhadap Pelayanan Administrasi Akademik Fakultas Ilmu Ekonomi Dan Bisnis Universitas Muhammadiyah Lamongan
}

\author{
Abdul Majid \\ Universitas Muhammadiyah Lamongan \\ majidumla1@gmail.com

\section{Ratna Nurdiana} \\ UNIPA PSDKU Kampus Lamongan \\ ratnanurdiana128@gmail.com

\section{Ninik Mas'adah \\ Universitas Muhammadiyah Lamongan \\ ninikmasadah6@gmail.com \\ Erna Nur Faizah \\ Universitas Muhammadiyah Lamongan \\ faizahnurerna@gmail.com}

\section{Suryani Yuli Astuti}

Universitas Muhammadiyah Lamongan

9suryani1976.ya@gmail.com
Abstrak
This study aimed at determining students' satisfaction toward the BAAK FEB UMLA service based on tangibles, responsiveness, reliability, empathy, and confidence. This research was a descriptive study with a quantitative approach. The population of this research was semester II students of Accounting and Management Study Program 2019-2020 as many as 41 students. The samples were obtained through census. The data collection technique was attitude scale. Then the data were analyzed using trend test and percentage of a frequency distribution. The results of this study indicated: 1) Students' Satisfaction based on Tangibles aspects was 74.62\%, 2) Students' Satisfaction based on Responsiveness aspects was $61.86 \%$, 3) Students' Satisfaction based on Reliability aspects was $72.96 \%, 4)$ Students' Satisfaction based on Empathy aspects was $71.77 \%$, 5) Students' Satisfaction based on Assurance aspects was $70.80 \%$.

\section{Kata Kunci Satisfaction, Service}




\section{PENDAHULUAN}

Pendidikan merupakan hal yang sangat penting dan setiap orang tua di zaman sekarang ini pola pikir orang tua sudah mempunyai target untuk mensekolahkan anaknya minimal di jenjang S1, dampaknya peminat anak yang mau kuliah semakian bertambah. Pendidikan tinggi dianggap telah menjadi wadah penghasil sumber daya manusia yang bermutu. Sejalan dengan pertumbuhan kebutuhan pendidikan tinggi maka perkembangan perguruan tinggi selalu menjadi perhatian masyarakat. Perkembangannya perguruan tinggi tidak hanya dilihat sebagai pusat ilmu pengetahuan, pusat penelitian, dan pusat pengabdian kepada masyarakat, tetapi juga suatu entitas korporat yang perlu bersaing untuk menjamin kelangsungan hidup. Perubahan ini dapat dilihat dari ketatnya persaingan kualitas layanan, harga, dan promosi perguruan tinggi.

Persaingan yang semakin ketat dan tuntutan kebutuhan masyarakat akan kualitas yang berorientasi pada nilai pengguna jasa pada akhirnya menekan organisasi untuk dapat menanggapinya dengan cepat, pada kondisi ini hal utama yang harus diprioritaskan oleh perguruan tinggi adalah kepuasan mahasiswa. Kepuasan mahasiswa ditentukan oleh kualitas yang dikehendaki mahasiswa, sehingga jaminan kualitas menjadi prioritas utama bagi setiap perguruan tinggi, yang saat ini dijadikan sebagai tolok ukur keunggulan daya saing perguruan tinggi (Maisaroh, 2005)

Manajemen peningkatan mutu pendidikan tinggi diartikan sebagai layanan profesional publik yang dijalankan dan diarahkan semaksimal mungkin untuk memberikan layanan yang sesuai atau melebihi standar. Artinya layanan yang diberikan perguruan tinggi harus berkualitas agar mendapatkan kepercayaan masyarakat atau publik. Ini berarti setidaknya perguruan tinggi harus memiliki kriteria dan standar pelayanan atau melakukan pengukuran layanan kepada para pelanggan dalam rangka meningkatkan kualitas pendidikannya. Sistem manajemen pengendalian mutu layanan perguruan tinggi terbagi dua, yaitu internal dan eksternal. Pada lingkup internal mencakup pengawasan penyelenggaraan pendidikan tinggi oleh perguruan tinggi guna mewujudkan visi misi serta untuk memenuhi kebutuhan pemegang kepentingan (pelanggan) melalui penyelenggaraan Tridharma Perguruan Tinggi. Lingkup eksternal saat ini lazim dilakukan melalui penilaian standar mutu oleh BAN PT (Badan Akreditasi Nasional Perguruan Tinggi) dan Lembaga Akreditasi Mandiri (LAM-PT).

Sistem Manajemen Mutu ISO secara umum menggunakan delapan klausul/prinsip utama, yaitu: berfokus pada pelanggan, kepemimpinan, peran serta setiap orang di dalam organisasi, pendekatan proses, pendekatan sistem, peningkatan terus menerus, pengambilan keputusan dengan pendekatan fakta, serta hubungan baik dengan pemasok. Menurut (Evans \& Lindsay, 2008), mutu mencakup perfection, consistency, eliminating waste, speed of delivery, compliance with policies and procedures, providing a good, usable product, doing it right the first time, delighting or pleasing customer and total customer service and satisfaction. Pemahaman kedua pendapat diatas mengarah pada pelayanan dan kepuasan pelanggan. Layanan dapat diartikan sebagai usaha yang dilakukan lembaga dalam rangka memenuhi kebutuhan pelanggan. Kepuasan adalah hasil pemenuhan dari konsumen bahwa pelayanan telah memberikan tingkat kenikmatan dimana tingkat pemenuhan ini bisa lebih atau kurang (Irawan, 2002) 
Salah satu prinsip ISO bahwa pengukuran kepuasan pelanggan wajib dilakukan sebagai umpan balik dari pelanggan terhadap sistem yang diterapkan. Ini berarti bahwa keberhasilan sebuah lembaga sangat ditentukan oleh mutu layanan yang diberikan. Pelayanan yang bermutu dapat diidentifikasikan melalui kepuasan pelanggan, sebagai lembaga pendidikan maka proses akademik merupakan proses inti, oleh karena itu pengukuran kepuasan pelanggan pada proses ini wajib dilakukan secara periodik. Berlandaskan pemahamam mutu diatas, dapat dikatakan bahwa saat ini pendidikan bukan lagi sebatas kemampuan untuk menghasilkan lulusan yang diukur secara akademik, tetapi sudah mengarah pada suatu bentuk kualitas pendidikan secara menyeluruh (Total Quality Education) yang berorientasi pada kepuasan pelanggan (Fatmawati, 2004). Pelanggan pendidikan terbagi ke dalam dua kelompok, yaitu pelanggan internal dan pelanggan eksternal. Pelanggan internal meliputi para pendidik dan staf pendukung. Pelanggan eksternal meliputi pelanggan eksternal utama adalah peserta didik; pelanggan eksternal sekunder adalah orang tua, pemerintah dan employers, serta pelanggan eksternal tersier adalah pasaran kerja, pemerintah dan masyarakat.

Berdasarkan realita tersebut maka perguruan tinggi sebagai lembaga penyedia jasa pendidikan harus berbenah dalam memberikan pelayanan agar memperoleh pengakuan masyarakat serta mampu bersaing. Menurut (Umaedi, 2010) layanan pendidikan dapat dibagi atas lima jenis pokok jasa pelayanan yaitu: pelayanan administrasi pendidikan, pelayanan pembelajaran, pelayanan ko- kurikuler, pelayanan penelitian, dan pelayanan keinformasian pendidikan. Layanan pendidikan yang diberikan harus memperhatikan mutu pendidikan dan kelembagaan. Perlu ada bukti prestasi, penilaian, sertifikasi kualitas, keberhasilan alumni dalam mendapatkan pekerjaaan yang relevan, serta hasil evaluasi sehingga memperoleh pengakuan masyarakat serta unggul dalam persaingan.

Aspek penilaian pendidikan yang berhasil dapat diindikasikan sebagai layanan pendidikan yang mampu menghasilkan output pendidikan yang sesuai dengan tuntutan masyarakat. Sukamto dalam (Jaedun, 2015) mengemukakan paradigma mutu pendidikan yang berorientasi pada klien didefinisikan sebagai ukuran sejauh mana program dan hasil keluaran tersebut telah memenuhi kebutuhan dan harapan klien. Ada tiga hal yang perlu dipahami oleh lembaga penyelenggara pendidikan untuk memenuhi kebutuhan dan harapan klien, yaitu: apa kebutuhan klien, bagaimana mengetahui kebutuhan klien, dan apa yang membuat mereka puas.

Penelitian empiris berkenaan dengan service quality untuk mengukur kinerja perusahaan secara keseluruhan ternyata banyak terfokus pada masalah pelayanan konsumen (consumer service quality) (Widjoyo et al., 2013). Hasil penelitian lainnya dilakukan oleh (Arimawati, 2013) menunjukkan bahwa variabel bukti fisik/nyata, kehandalan/reliability, responsiveness/daya tanggap, jaminan, empati, semua memiliki pengaruh positif dan signifikan terhadap kepuasan mahasiswa.

Pelanggan adalah orang-orang yang menggunakan atau memakai produk dari lembaga. Produk dapat berupa barang ataupun jasa. Perguruan tinggi berkegiatan memberikan layanan pendidikan. Produk perguruan tinggi berupa ilmu pengetahuan dan pendidikan, dimanfaatkan atau digunakan oleh mahasiswa, dengandemikian mahasiswa adalah pelanggan. Ilmu pengetahuan dan pendidikan adalah sesuatu yang tidak kelihatan, maka perguruan tinggi dapat pula dipandang sebagai industri jasa. Industri jasa dalam 
mencapai keberhasilan dan kualitas layanan selama ini selalu berfokus pada pelanggan, begitu juga di perguruan tinggi usaha memenuhi kebutuhan mahasiswa harus menjadi fokus utama dalam mengelola mutu/kualitas layanan pendidikan. Mahasiswa menjadi sangat penting selain sebagai pelanggan utama adalah karena keberhasilan proses belajar sangat tergantung dari partisipasi mahasiwa, betapapun pandainya para dosen yang mengajar.

Konsep manajemen mutu perguruan tinggi, bahwa pelaksanaan pendidikan harus melakukan monitoring dan evaluasi, maka perlu untuk mengetahui bagaimana kepuasan mahasiswa terhadap layanan yang sudah diberikan akan berpengaruh terhadap kualitas layanan pendidikan yang diberikan.

Kepuasan adalah respon atau tanggapan konsumen mengenai pemenuhan kebutuhan. Kepuasan merupakan penilaian mengenai ciri atau keistimewaan produk atau jasa, atau produk itu sendiri yang menyediakan tingkat kesenangan konsumen berkaitan dengan pemenuhan kebutuhan konsumsi konsumen (Zeithaml et al., 2010), kepuasan adalah persepsi atau penilaian konsumen terhadap pemenuhan kebutuhan atau ketersediaan produk atau jasa yang diterimanya. Ini berarti kepuasan pelayanan dipengaruhi oleh kualitas layanan yang diberikan.

Keberhasilan pelayanan maka perlu adanya pengukuran. Secara lebih lanjut pengukuran kepuasan menurut Philip Kotler dalam (Tjiptono, 2001) didasarkan pada determinan kualitas yang dapat dirincikan diantaranya 1) Berwujud (Tangibles), 2)

Daya tanggap (Responsiveness), 3) Kepercayaan atau kehandalan (Reliability), 4) Empati (Emphaty), 5) Keyakinan (Assurance).

Fakultas Ekonomi dan Bisnis UMLA dalam melaksanakan pelayanan pendidikan dibagi menjadi beberapa fungsi yaitu, Subbag Pendidikan, Subbag Kemahasiswaan dan Alumni, subbag Keuangan dan Akuntansi, Subbag Umum, Kepegawaian, dan Perlengkapan, serta perpustakaan FEB UMLA. Secara fungsional masing-masing subbag dipimpin oleh seorang Kepala Sub bagian yang bertanggungjawab kepada Dekan.

Struktur organisasi layanan bidang akademik terdiri dari subbag Pendidikan, dan Perpustakaan FEB berada di bawah pembinaan Wakil Dekan I. Layanan akademik menjalankan fungsi sebagai pengelola administrasi akademik dan evaluasi, registrasi dan statistik, serta sarana akademik. Bagian Keuangan dan umum kepegawaian menjalankan fungsi administrasi perencanaan akademik dan fisik, pengumpulan dan pengelolaan data, serta layanan informasi dibawah pembinaan Wakil Dekan II. Layanan bidang kemahasiswaan dan alumni dibawah pembinaan Wakil Dekan III bertugas melaksanakan administrasi minat, penalaran dan informasi kemahasiswaan, serta layanan kesejahteraan mahasiswa.

Layanan akademik Di FEB UMLA layanan dilakukan oleh BAAK. Berkaitan dengan fungsinya yang selalu berhubungan dengan mahasiswa, maka layanan akademik dianggap merupakan salah satu pendukung terwujudnya pendidikan yang berkualitas, perlu adanya inovasi manajemen dan pengukuran atau evaluasi dari para pengguna jasa layanan (mahasiswa), penting diingat bahwa orang yang paling menikmati kesuksesan sebuah perguruan tinggi adalah mahasiswanya.

Biro Administrasi Akademik dan Kemahasiswaan Universitas Muhammadiyah Lamongan menyediakan jenis layanan akademik berupa pengaturan jadwal perkuliahan, nilai, KRS, yudisium, dan urusan kemahasiswaan yang berkaitan dengan akademik 
mahasiswa. Realisasi pelaksanaan layanan akademik di FEB UMLA masih terdapat kesenjangan antara harapan mahasiswa dan kondisi aslinya. Berdasarkan hasil observasi dan pengamatan dapat dijelaskan berbagai permasalahan tersebut diantaranya: 1) Tidak adanya ruang tunggu yang memadai, mahasiswa yang menunggu layanan hanya disediakan kursi di luar ruangan tanpa ada fasilitas pendukung seperti koran dan sejenisnya. 2) Komputer akses SIAKAD yang kurang memadai, tersedia empat perangkat komputer, padahal dua komputer biasa digunakan untuk urusan perijinan surat, dan dua komputer tersebut sering tidak bisa digunakan untuk akses karena dimatikan. 3) Petugas pelayanan tidak selalu berada di loket layanan ketika dimintai layanan, sehingga ketika meminta pelayanan harus memanggil terlebih dahulu karena petugas sedang mengerjakan pekerjaan lainnya. 4) Tidak dimanfaatkannya kotak saran yang sudah ada untuk menjaring keluhan dan saran dari mahasiswa sehingga tidak pernah ada tindak lanjut khusus tentang keluhan mahasiswa meskipun sudah disampaikan langsung. 5) Terkadang tidak ada informasi tertulis di papan informasi maupun di loket layanan mengenai program atau tata cara layanan yang baru, sehingga membingungkan

\section{LANDASAN TEORI}

Menurut (Tjiptono, 2001) Istilah service dalam Bahasa Indonesia setidaknya memiliki tiga kata yakni jasa, layanan, dan servis, sebagai jasa layanan umumnya mencerminkan produk tidak berwujud (intangible) atau sektor industri spesifik seperti pendidikan, kesehatan, telekomunikasi, transportasi, asuransi, perbankan, perhotelan dan seterusnya. Hakikatnya layanan sebagai jasa bersifat intangible (tidak teraba), yang merupakan pemenuhan kebutuhan dan tidak harus terikat pada penjualan produk atau pelayanan lain. Layanan dapat diartikan sebagai segala sesuatu yang dilakukan pihak tertentu (individu ataupun kelompok) kepada pihak lain (individu ataupun kelompok). Salah satu contohnya adalah layanan pelanggan, yang mencakup aktivtas menjawab pertanyaan pelanggan, menangani komplain, memproses pesanan, menginstalasi produk, dan mereparasi kerusakan.

Menurut Philip Kotler dalam (Tjiptono, 2001) mengatakan bahwa dalam jasa memiliki lima dimensi kualitas pelayanan yaitu; tangible (bukti fisik), reliable (kehandalan), responsiveness (daya tanggap), assurance (jaminan) dan emphaty (empati) yang akan dijelaskan sebagai berikut:

1) Tangible (bukti fisik) ini berarti bahwa mahasiswa menghendaki adanya bukti yang dapat ditunjukan oleh karyawan yang dapat memuaskan mahasiswa seperti hal yang menyangkut ketepatan waktu, kemudahan, keramahan, dan interaksinya dengan mahasiswa.

2) Reliable (kehandalan) dalam artian karyawan yang handal dalam mengerjakan tugastugas yang menjadi hak mahasiswa.

3) Responsiveness (daya tanggap) berarti karyawan harus memiliki daya tanggap terhadap keluhan dan kebutuhan mahasiswa. Baik yang itu yang berkaitan dengan admnistrasi maupun hal lain yang menyangkut segala kebutuhannya

4) Assurance (jaminan) dalam artian karyawan harus memiliki pengetahuan,kompetensi, kesopanan, dan sifat dapat dipercaya, bebas dari bahaya, resiko,atau keragu-raguan. Jaminan terhadap hal-hal tersebut akan ditunjukan 
lewatinteraksi mahasiswa dengan pimpinan, dosen dan karyawan dalam lingkupakademis.

5) Empathy (empati) yaitu meliputi kemudahan bagi mahasiswa dalam menjalin relasi, komunikasi yang baik, perhatian pribadi, dan pemahaman kepada karyawan atas kebutuhan individu para mahasiswa.

Kata kepuasan atau satisfaction berasal dari bahasa latin "satis" (artinya cukup baik, memadai) dan "facio" (melakukan atau membuat). Secara sederhana kepuasan dapat diartikan sebagai upaya pemenuhan sesuatu atau membuat sesuatu memadai. Konsep kepuasan pelanggan masih bersifat abstrak, meski demikian kepuasan pelanggan menjadi konsep sentral dalam teori dan praktik pemasaran, serta merupakan salah satu tujuan esensial bagi aktivitas bisnis. Menurut (Tjiptono, 2001) Pencapaian kepuasan dapat merupakan proses yang sederhana maupun kompleks. Dalam hal ini peranan setiap individu dalam service encounter sangatlah penting dan berpengaruh terhadap kepuasan yang dibentuk. Sesuai dengan pendapat diatas istilah kepuasan jika ditinjau dari perilaku konsumen menjadi sesuatu yang kompleks. Konsumen dalam memberikan penilaian sesuatu biasanya akan lebih kecewa terhadap jasa dibandingkan barang. Alasannya adalah karena mereka juga ikut terlibat dalam proses penciptaan jasa.

Selaian toeri ada hasil hasil penelitian yang dijadikan sebagai rujukan diantaranya (1) penelitian Indah Elza Putri dalam (Alfiani, 2016) memiliki persamaan dengan penelitian yang akan dilakukan penulis pada indikator kualitas layanan yang digunakan. Perbedaannya pada penelitian yang dilakukan Indah Elza Putri mengukur tanggapan mahasiswa beserta penilaian kualitas layanan, sedangkan penulis hanya mendeskripsikan kepuasan mahasiswa terhadap layanan administrasi akademik tanpa penilaian kualitas layanan. (2) penelitian yang dilakukan oleh Muhammad Joko Triono (Alfiani, 2016) memiliki persamaan dengan penelitian yang akan dilakukan oleh penulis yaitu sama sama menilai tentang layanan administrasi akademik. Perbedaannya adalah pada variabel yang digunakan. Penelitian ini hanya memiliki 1 variabel yaitu kepuasan mahasiswa, sedangkan pada penelitian Muhammad Joko Triono menggunakan 2 variabel yakni layanan administrasi untuk memberikan kepuasan mahasiswa dan tingkat harapan mahasiswa. (3) penelitian yang dilakukan oleh Wagiran (Alfiani, 2016), memiliki persamaan dengan penelitian yang akan dilakukan oleh penulis yaitu sama-sama hanya mendeskripsikan kepuasan mahasiswa. Adapun perbedaannya pada penelitian Wagiran mengukur layanan akademik dan non akademik, sedangkan penelitian ini hanya menilai lingkup layanan administrasi akdemik. Berdasarkan penjelasan diatas dapat diketahui bahwa penelitian yang dilakukan oleh penulis belum pernah diteliti oleh peneliti sebelumnya. Beberapa penelitian tersebut menjadi acuan bagi penelitian ini, dan memberikan gambaran mengenai kepuasan mahasiswa terhadap layanan akademik subbag Pendidikan

\section{METODE PENELITIAN}

Penelitian kepuasan mahasiswa terhadap pelayanan Akademik FEB UMLA ini merupakan penelitian deskriptif dengan pendekatan kuantitatif. Populasi dalam penelitian ini berjumlah 41 Mahasiswa FEB UMLA. Sampel dalam penelitian adalah keseluruhan jumlah populasi diambil sebagai sampel. Dengan demikian jumlah sampel sama dengan jumlah populasi (sensus atau sampel jenuh). Menurut (Arikunto, 2002) jika jumlah 
populasi kurang dari 100 maka lebih baik diambil semua. Teknik sampling yang digunakan adalah Sensus. Teknik analisis data menggunakan teknik analisis deskriptif yaitu uraian penggambaran untuk menjelaskan jawaban yang diberikan responden dalam skala dengan Analisa

1. Uji Kecenderungan

1) Menghitung mean ideal dan standar deviasi ideal
$\mathrm{Mi}=1 / 2(\mathrm{ST}+\mathrm{SR})$
$\mathrm{SDi}=1 / 6(\mathrm{ST}-\mathrm{SR})$ Keterangan:
$\mathrm{Mi}=$ mean ideal
SDi $=$ standar deviasi ideal
ST $=$ skor tertinggi
$\mathrm{SR}=$ skor terendah

2) Menentukan skala skor mentah dengan kategorisasi kepuasan berdasarkan mean ideal dan standar deviasi ideal dengan rumus menurut Suprian dalam (Alfiani, 2016) sebagai berikut :

Tabel 1 skala skor mentah dengan kategorisasi kepuasan

\begin{tabular}{|c|l|l|}
\hline No. & \multicolumn{1}{|c|}{ Kategori } & \multicolumn{1}{c|}{ Rentang } \\
\hline 1. & Sangat Puas & $>\mathrm{Mi}+(1,5 \times \mathrm{SDi})$ \\
\hline 2. & Puas & $\mathrm{Mi}$ sampai $\mathrm{Mi}+(1,5 \times \mathrm{SDi})$ \\
\hline 3. & Tidak Puas & $\mathrm{Mi}-(1,5 \times \mathrm{SD})$ sampai Mi \\
\hline 4. & Sangat Tidak Puas & $<\mathrm{Mi}-(1,5 \mathrm{x}$ SDi $)$ \\
\hline
\end{tabular}

Sumber: Hasil Olah Data Penelitian, 2020

3) Menentukan frekuensi dan membuat persentase untuk menafsirkan data kecenderungan masing-masing subjek penelitian secara umum

2. Perhitungan Persentase

Persentase digunakan untuk mengetahui gambaran umum mengenai kepuasan mahasiswa terhadap pelayanan administrasi akademik subbag FEB UMLA. Persentase diperoleh dengan memperhatikan sebaran skor pada distribusi frekuensi yang terjadi dan skala kepuasan yang diukur dari besarnya persentase yang diukur. Menurut Sudjana dalam (Alfiani, 2016) untuk dapat menafsirkan data yang diperoleh perlu dilakukan penskoran data penelitian dengan rumus:

Keterangan:

n : Jumlah skor Ideal

f : Jumlah skor, yang diperoleh melalui;

a. Sangat Puas : jumlah butir bernilai 4 x Skor SP ( 4 )

b. Puas : jumlah butir bernilai 3 x Skor P ( 3 )

c. Tidak Puas : jumlah butir bernilai $2 \times$ Skor TP (2)

d. Sangat Tidak puas : jumlah butir bernilai 1 x Skor STP ( 1 )

Hasil perolehan skor kemudian ditafsirkan dengan menghitung rentang skala dengan menghitung selisih persentase tertinggi dan terendah dibagi dengan jumlah kategori sebagai berikut:

$$
\mathrm{RS}=\frac{m-n}{k}=\frac{100-25}{4}=18,75
$$


Berdasarkan hasil rentangan di atas maka dasar interpretasi persentase yang digunakan adalah sebagai berikut:

Tabel. 2 Kriteria Interpretasi Skor Kepuasan Pelayanan

\begin{tabular}{|c|l|c|}
\hline No. & \multicolumn{1}{|c|}{ Kategori } & \multicolumn{1}{c|}{ Rentang } \\
\hline 1. & Sangat Tinggi & $75,10 \%-100 \%$ \\
\hline 2. & Tinggi & $56,26 \%-75,00$ \\
\hline 3. & Rendah & $37,51 \%-56,25 \%$ \\
\hline 4. & Sangat rendah & $0,00 \%-37,50 \%$ \\
\hline
\end{tabular}

Sumber: Hasil Olah Data Penelitian, 2020

\section{HASIL PENELITIAN}

\section{Uji Kecenderuangan}

Kepuasan mahasiswa terhadap layanan akademik diukur dengan 21 pernyataan dengan skor 1-4. Hasil penelitian menunjukkan skor tertinggi 79 dari skor tertinggi yang dapat dicapai sebesar 84, dan skor terendah 46 dari skor terendah yang dapat dicapai sebesar 21. Mean sebesar 61, dan standar deviasi sebesar 6,8. Berdasarkan hasil perhitungan tersebut kepuasan mahasiswa didistribusikan dengan kategori sebagai berikut :

Tabel 3 Kategori kepuasan mahasiswa terhadap pelayanan adminsitrasi Akademik

\begin{tabular}{clcc}
\hline No & \multicolumn{1}{c}{ Katagori } & F & $\%$ \\
\hline 1 & Sangat Puas & 8 & 19,51 \\
2 & Puas & 17 & 41,46 \\
3 & Tidak Puas & 14 & 34,15 \\
4 & Sangat Tidak Puas & 2 & 4,88 \\
\hline & Jumlah & 41 & 100
\end{tabular}

Sumber: Data diolah 2020

Dari tabel 3 diatas hasil uji kecenderungan di peroleh tanggapan mahasiswa puas $41,46 \%$, tidak puas $34,15 \%$ sangat puas $19,51 \%$ dan sangat tidak puas $4,88 \%$, secara keseluruhan tanggapan responden lebih dari separuh mahasiswa mengatakan puas terhadap pelayanan administrasi akademik

\section{Perhitungan Presentase}

Rata-rata hasil skor kepuasan mahasiswa terhadap pelayanan administrasi akademik FEB UMLA ditunjukkan dengan skala sikap sebagai berikut : 
Tabel 4 Skor Kepuasan Mahasiswa terhadap pelayanan Administrasi Akademik

\begin{tabular}{|c|c|c|c|c|}
\hline Skala & Nilai & Jumlah Butir & Skor & $\%$ \\
\hline Sangat Puas & 4 & 277 & 1108 & 32,17 \\
\hline Puas & 3 & 437 & 1311 & 38,07 \\
\hline Tidak Puas & 2 & 80 & 160 & 4,65 \\
\hline Sangat Tidak Puas & 1 & 67 & 67 & 1,95 \\
\hline \multicolumn{3}{|c|}{ Jumlah } & 2646 & 76,83 \\
\hline
\end{tabular}

Sumber: Data diolah 2020

Berdasarkan tabel 4. diketahui bahwa hasil kepuasan mahasiswa sebesar $76,83 \%$ atau sangat memuaskan. Rincian kepuasan jika ditinjau per aspek disajikan pada tabel sebagai berikut:

Tabel 5 Skor Kepuasan Mahasiswa terhadap pelayanan Administrasi Akademik per aspek.

\begin{tabular}{clccc}
\hline No & \multicolumn{1}{c}{ Aspek } & Skor Total & \% Per Aspek & Katagori \\
\cline { 1 - 4 } 1 & Tangibles & 328 & 74.62 & \\
2 & Responsiveness & 175 & 61.86 & \\
3 & Reliability & 269 & 72.96 & \multirow{2}{*}{ PUAS } \\
4 & Emphatthy & 186 & 71.77 & \\
5 & Assurence & 131 & 70.80 & \\
\cline { 1 - 3 } Rata Rata & & 70.40 & \\
\cline { 1 - 3 } & \multicolumn{2}{c}{}
\end{tabular}

Sumber: Data diolah 2020

Tabel 5 menunjukkan aspek tangibles mencapai $74.62 \%$, aspek responsiveness $61.86 \%$, aspek realibility $72.96 \%$, aspek empathy $71.77 \%$, dan aspek assurance $70.20 \%$. Rata-rata hasil kepuasan diukur per aspek adalah $70,40 \%$ atau bernilai memuaskan.

\section{Pembahasan}

Berdasarkan analisis data yang dilakukan dengan menghitung sebaran skor di setiap distribusi frekuensi kemudian diinterpretasikan dengan kriteria persentase maka hasil penelitian dapat dijelaskan sebagai berikut :

\section{Kepuasan Mahasiswa Terhadap Pelayanan Administrasi Akademik Fakultas Ekonomi Bisnis Universitas Muhammadiyah Lamongan}

Pengukuran kepuasan dilakukan terhadap mahasiswa FEB UMLA terdiri dari delapan program studi. Butir pernyataan yang digunakan sebanyak 21 butir dengan skala skor 1-4. Aspek yang diukur meliputi aspek keberwujudan (Tangibles), daya tanggap (Responsiveness), kepercayaan (Reliability), empati (Emphaty), dan keyakinan (Assurance).

Hasil tabulasi data menunjukkan kepuasan mahasiswa secara umum dinilai sudah sangat memuaskan dengan nilai sebesar 76,83 \%. Adapun kepuasan jika diukur per aspek menunjukkan rata-rata sebesar 70,40\%. Kondisi ini dapat diasumsikan bahwa masih terdapat nilai ketidakpuasan sebesar 23,17\%. Menurut 
aspek hasil menunjukkan masih terdapat ketidakpuasan sebesar 29,60\%. Kekurangan tersebut jika ditinjau per aspek antara lain :

1) Aspek Tangibles (Keberwujudan)

Secara umum semua indikator kepuasan dinilai sudah memuaskan dengan hasil kepuasan $74,62 \%$. Artinya pelayanan administrasi akademik yang diberikan sudah baik. Hal ini menunjukkan bahwa aspek tangibles adalah sesuatu yang penting untuk mewujudkan layanan prima, sesuai pendapat Parasuraman (Tjiptono, 2001) yang menyatakan bahwa aspek tangibles terkait dengan keinginan mahasiswa mengenai bukti yang menyangkut ketepatan waktu, kemudahan, keramahan, dan interaksinya dengan mahasiswa.

Berdasarkan hasil kepuasan didapatkan bahwa masih terdapat 25.38\% aspek yang masih belum memuaskan. Guna meningkatkan kepuasan pelanggan perlu ada perbaikan. Indikator yang paling penting untuk diperbaiki adalah sikap kesiapsiagaan petugas di meja layanan sesuai tugas masing-masing dan pembaharuan alur layanan serta tata letaknya agar mudah diketahui, kedua indikator ini penilaian mahasiswa cenderung belum memuaskan. Kondisi nyata memang demikian petugas kadang-kadang siap selalu di depan loket terkadang tidak. Hal ini menunjukkan bahwa belum ada upaya petugas untuk mewujudkan pelayanan prima, alur layanan mahasiswa memang banyak yang tidak.

2) Aspek Responsiveness (Daya Tanggap)

Semua indikator kepuasan dinilai sudah memuaskan dengan hasil kepuasan $61.86 \%$ atau sudah baik. Artinya aspek ini dinilai penting untuk meningkatkan kepuasan mahasiswa, sesuai dengan prinsip pelayanan public yakni pelayanan jelas dan sepenuh hati sesuai dengan Kmenpan No 63 tahun 2003, bahwa petugas berwenang bertanggung jawab dalam memberikan pelayanan dan penyelesaian keluhan persoalan dalam pelaksanaan pelayanan publik. Hasil kepuasan masih menunjukkan adanya kecenderungan ketidakpuasan aspek sebesar 38.2\%, dengan demikian perlu adanya peningkatkan kepuasan pelayanan.

Hal yang utama untuk diperbaiki adalah mengenai sikap dan sambutan petugas dalam melayani pelanggan dengan senyuman, adanya pelatihan dan training tentang pelayanan kepada para petugas, karena memang kenyataannya terkadang saat sibuk seringkali petugas sambil bekerja ketika melayani, bahkan mahasiswa disuruh untuk melayani diri sendiri. Indikator ini padahal sangat penting untuk mewujudkan pelayanan prima. Sambutan atau kesan pertama tentu akan selalu diingat oleh pelanggan, dan akan membentuk image bagi lembaga. Kesan pertama saja tidak menyenangkan maka untuk meminta layanan di waktu selanjutnya pelanggan pasti akan memikirkannya kembali.

\section{3) Aspek Realibility (Kepercayaan)}

Indikator realibility dinilai sudah memuaskan dengan hasil kepuasan 72,99\%. Artinya pelayanan administrasi akademik yang diberikan oleh subbag pendidikan sudah cukup baik. Hal ini menunjukkan bahwa aspek kehandalan petugas dalam melayani ini penting. Kemampuan petugas dalam menjaga dan memperhatikan pelanggan, akan menimbulkan rasa kepercayaan pelanggan 
terhadap petugas dan sistem operasional yang ada untuk menyelesaikan masalah mereka.

Hal yang perlu ditingkatkan adalah kecepatan penyelesaian masalah oleh petugas. Menurut mahasiswa indikator ini masih perluh ditingkatkan lagi, butuh adanya tindakan spontanitas petugas menunjukkan keinginan untuk menyelesaikan masalah pelanggan. Dengan demikian masalah akan segera teratasi dengan cepat, terkait dengan sistem ketika ada pembaharuan lembaga atau petugas hendaknya memberikan pengumuman. Kenyataannya banyak mahasiswa yang tidak mengetahui jika ternyata saat ini sudah ada sistem baru tentang pelayanan surat dan form ijin observasi melalui internet. Berdasarkan hal tersebut maka penilaian terhadap kejelasan prosedur layanan dinilai rendah oleh mahasiswa. Dua indikator tersebutlah yang menyumbang kecenderungan ketidakpuasan sebesar $27.01 \%$

4) Aspek Empathy (Empati)

Indikator kepuasan dinilai sudah memuaskan dengan hasil kepuasan 71.77\% atau baik. Hal ini menunjukkan bahwa antara mahasiswa dan petugas sudah terjadi hubungan komunikasi dan pemahaman kebutuhan yang baik. Berdasarkan hasil tersebut masih terdapat $28.23 \%$ aspek yang belum memuaskan. Indikator terendah kesesuaian layanan dengan yang dijanjikan. Hal ini mengarah pada konsep komunikasi pada layanan. Pelayanan (service) ketika penyedia jasa memberikan pelayanan kepada pelanggannya (customer) akan menimbulkan tanggapan (feedback). Tanggapan dapat berupa reaksi balik penerima terhadap pesan yang dilontarkan dan menimbulkan pengetahuan, sikap, dan tingkah laku secara keseluruhan pada diri penerima.

Demikian halnya dengan pelayanan, apabila perusahaan sebagai sumber (komunikator) memberikan pelayanan baik lewat pesan maupun tindakan kepada pengguna jasa (komunikan/penerima) pada akhirnya akan memunculkan lagi umpan balik (tanggapan) kepada pihak sumber (komunikator). Pelayanan yang baik pasti menghasilkan tanggapan positif, begitupun sebaliknya, perlu adanya komitmen petugas yang lebih tinggi terhadap kesesuaian janji dengan layanan yang diberikan.

5) Aspek Assurance (Keyakinan)

Indikator kepuasan dinilai sudah memuaskan dengan hasil kepuasan $70.8 \%$. Artinya pelayanan administrasi akademik yang diberikan sudah baik. Hal ini menunjukkan bahwa aspek assurance adalah sesuatu yang penting untuk mewujudkan layanan prima. Assurance identik dengan kemampuan dan kredibilitas front line staf (pegawai pelayanan).

Kredibilitas dan kemampuan terwujud dalam sikap nyata berupa kemampuan dalam menjawab, dan kompetensi tugasnya. Hal ini sesuai dengan kondisi nyata di subbag pendidikan bahwa indikator pemenuhan layanan dan tanggungjawab petugas terhadap layanan sudah memuaskan. Meskipun demikian perlu adanya peningkatan kemampuan petugas dalam membangun rasa percaya kepada pelanggan, sejalan dengan teori yang mengatakan bahwa loyalitas berawal dari kepercayaan. Kondisi ini terlihat dari masih adanya 29,2\% aspek yang menyatakan tidak puas. 


\section{V.SIMPULAN}

Berdasarkan hasil penelitian dan pembahasan mengenai kepuasan mahasiswa terhadap pelayanan administrasi akademik FEB Universitas Muhammadiyah Lamongan maka dapat disumpulkan kepuasan Mahasiswa berdasarkan aspek Tangibles secara umum memiliki nilai sebesar $74.62 \%$ (Memuaskan), kepuasan Mahasiswa berdasarkan aspek Responsiveness secara umum memiliki nilai sebesar 61.86\% (Memuaskan), kepuasan Mahasiswa berdasarkan aspek Realibility secara umum memiliki nilai sebesar 72,96\%, (Memuaskan), kepuasan Mahasiswa berdasarkan aspek Empathy secara umum memiliki nilai sebesar 71,77\%. (Memuaskan), dan kepuasan Mahasiswa berdasarkan aspek Assurance secara umum memiliki nilai sebesar $70.80 \%$, (Memuaskan).

\section{DAFTAR RUJUKAN}

Alfiani, A. (2016). Kepuasan Mahasiswa terhadap pelayanan administrasi akademik Subbag Pendidikan FKIP Universitas Negeri Jogja (Vol. 9, Issue 2) [Universitas Negeri Yogyakarta]. https://doi.org/10.5151/cidi2017-060

Arikunto. (2002). Metodelogi Penelitian Suatu Pendekatan Proposal. PT. Rineke Cipta.

Arimawati, R. (2013). Pengaruh Kualitas Pelayanan Kinerja Pegawai Administrasi Akademik Terhadap Kepuasan Mahasiswa Fakultas Ekonomika dan Bisnis Uiversitas Diponegoro [UNIVERSITAS DIPONEGORO]. In Diponegoro Journal of Management (Vol. 2, Issue 2). http://ejournal-

s1.undip.ac.id/index.php/djom\%0Ahttp://eprints.undip.ac.id/39016/1/ARIMAWA TI.pdf

Evans, J. R., \& Lindsay, W. M. (2008). The Management and Control of Quality. The Management and Control of Quality, 768.

Fatmawati, E. (2004). Analisis Kualitas Pelayanan Pada Bagian Administrasi Fakultas Ekonomi Undip. JIAKP, 1(2), 312-334.

Irawan, H. (2002). 10 prinsip kepuasan pelanggan. Elex Media Komputindo. https://onesearch.id/Record/IOS4670.JATIM000000000030113\#description

Jaedun, A. (2015). Survei Tingkat Kepuasan Konsumen Terhadap Kualitas Pelayanan Publik Bidang Pendidikan Di Daerah Istimewa Yogyakarta. 3(2), 54-67. http://repositorio.unan.edu.ni/2986/1/5624.pdf

Maisaroh, S. (2005). PENGARUH MANAJEMEN MUTU LAYANAN TERHADAP KEPUASAN PESERTA DIDIK DI UNIVERSITAS PGRI YOGYAKARTA Siti Maisaroh *) [UNIVERSITAS PGRI YOGYAKARTA]. http://ekonomi.upy.ac.id/ekonomi/files/PENGARUH MANAJEMEN MUTU 


\section{LAYANAN TERHADAP KEPUASAN PESERTA DIDIK DI UNIVERSITAS PGRI YOGYAKARTA_SITI MAISAROH_.pdf}

Tjiptono. (2001). Manajemen Jasa (Edisi Pert). Liberty.

Umaedi. (2010). Manajemen Berbasis Sekolah. Universitas Terbuka.

Widjoyo, I. O., Rumambi, L. J., \& Kunto, Y. S. (2013). Analisa Pengaruh Kualitas Layanan terhadap Kepuasan Konsumen pada Layanan Drive Thru McDonald's Basuki Rahmat Surabaya. Jurnal Manajemen Pemasaran, 1(1), 1-12.

Zeithaml, V. A., Bitner, M. J., \& Gremler, D. D. (2010). Services Marketing Strategy. Wiley International Encyclopedia of Marketing, December. https://doi.org/10.1002/9781444316568.wiem01055 